\title{
Family 1 carbohydrate binding-modules enhance saccharification rates
}

\author{
Bruno Luan Mello and Igor Polikarpov*
}

\begin{abstract}
Cellulose degrading enzymes usually have a two-domain structure consisting of a catalytic domain and a non-catalytic carbohydrate-binding module. Although it is well known the importance of those modules in cell wall degrading process, their function is not yet fully understood. Here, we analyze the cellulose-hydrolysis activity enhancement promoted by the cellobiohydrolase I carbohydrate-binding module from Trichoderma harzianum. It was cloned, expressed, purified and used in combination with either a commercial cellulase preparation, T. reesei cellobiohydrolase I or its separate catalytic domain to hydrolyze filter paper. In all cases the amount of glucose released was increased, reaching up to $30 \%$ gain when the carbohydrate-binding module was added to the reaction. We also show that this effect seems to be mediated by a decrease in the recalcitrance of the cellulosic substrate. This effect was observed both for crystalline cellulose samples which underwent incubation with the CBM prior to application of cellulases and for the ones incubated simultaneously. Our studies demonstrate that family 1 carbohydrate-binding modules are able to potentiate the enzymatic degradation of the polysaccharides and their application might contribute to diminishing the currently prohibitive costs of the

lignocellulose saccharification process.
\end{abstract}

Keywords: Carbohydrate binding-module; Cellulose binding-domain; Enzymatic hydrolysis; Cellulosic ethanol; Amorphogenesis

\section{Introduction}

Plant cell walls are complex structures, which the main component is cellulose, a linear homopolymer of thousands of glucose residues linked by $\beta$-1,4-glycosidic bonds. In plant cell walls, cellulose is found as fibers composed of many chains that pack together by regular $\mathrm{H}$-bonding networks in a crystalline structure, though imperfections and amorphous regions are also observed (Hon 1994; Knox 2008). In higher plants, these fibers are encapsulated by hemicellulose and lignin in a structure called lignocellulose (Atalla 1987).

The enzymatic hydrolysis of cellulose into glucose requires the synergistic action of a set of cellulases traditionally grouped as endoglucanases (EC 3.2.1.4), exoglucanases (EC 3.2.1.91 and 3.2.1.176) and $\beta$-glucosidases (EC 3.2.1.21) (Lynd et al. 2002; Saharay et al. 2010; Smith et al. 2012). The glucose released can be then fermented to ethanol by

\footnotetext{
* Correspondence: ipolikapov@ifsc.usp.br

Grupo de Biotecnologia Molecular, Instituto de Física de São Carlos,

Universidade de São Paulo. Av. Trabalhador Sancarlense, 400, São Carlos, SP CEP 13560-970, Brazil
}

国

Springer

(c) 2014 Mello and Polikarpov; licensee Springer. This is an Open Access article distributed under the terms of the Creative Commons Attribution License (http://creativecommons.org/licenses/by/2.0), which permits unrestricted use, distribution, and reproduction in any medium, provided the original work is properly cited.

available technologies. Hence, biomass-derived cellulose is a promising feedstock for the production of a secondgeneration biofuel with little contribution to global warming.

Cellulases from aerobic organisms generally have a two-domain structure consisting of a catalytic domain (CD) and a carbohydrate-binding module (CBM) (Tomme et al. 1988). CBMs are classified into families based on amino acid sequence similarity and the majority of the fungal cellulases CBMs belong to family 1 (CAZy; Cantarel et al. 2009). It is well known that the CBMs act targeting the CDs to the insoluble substrate and increasing the cellulases local concentration (Reinikainen et al. 1992; Bolam et al. 1998; Carrard et al. 2000). As a consequence, removal of the CBMs reduces dramatically the activity of cellulases toward insoluble substrates even though the activity remains largely unchanged for the soluble ones (Irwin et al. 1993; Mansfield et al. 1999; Colussi et al. 2011). Although in the eighties it was already speculated that CBMs could potentiate polysaccharide deconstruction (Knowles et al. 1987), the molecular mechanism of such phenomenon is still not clear. 
While growing body of evidence shows that CBMs from the family 1 might have a disruptive function (Din et al. 1991; Gao et al. 2001; Xiao et al. 2001; Pinto et al. 2004; Wang et al. 2008; Hall et al. 2011) and act to enhance cellulase activity (Gao et al. 2001; Lemos et al. 2003; Moser et al. 2008; Hall et al. 2011), this effect is frequently not taken into account (Herve et al. 2010; Varnai et al. 2013). The elucidation of molecular mode of CBM action is of both scientific and technological importance, since its understanding may lead to a decrease in the cellulase loads used in the paper, textile and bioethanol industries.

Here, we report the use of a family 1 CBM to increase the saccharification of a model cellulosic substrate. To achieve this goal, the CBHI CBM from T. harzianum $\left(\mathrm{CBM}_{\mathrm{CBHI}}\right)$ was cloned and expressed in Escherichia coli fused to a small ubiquitin-like modifier (SUMO). The $\mathrm{CBM}_{\mathrm{CBHI}}$ was then released from the CBM-SUMO fusion protein by limited proteolysis and purified by size-exclusion chromatography. A commercial cellulase cocktail, the CBHI from Trichoderma reesei (TrCBHI) and the $\mathrm{CBHI} C \mathrm{CD}$ from $T$. reesei $\left(\mathrm{CD}_{\mathrm{CBHI}}\right)$ were then supplemented with the purified $\mathrm{CBM}$ and the activity enhancement on the filter paper hydrolysis was analyzed.

\section{Material and methods}

\section{Cloning of $\mathrm{CBM}_{\mathrm{CBH}}$}

Standard molecular biology techniques were used as described elsewhere (Michael and Joseph 2012). A plasmid cloned previously by our group with the gene for cellobiohydrolase I from Trichoderma harzianum [GenBank: AF223252.1] (Bogo et al. 2010) was used to amplify the $\mathrm{CBM}_{\mathrm{CBHI}}$ sequence by polymerase chain reaction (PCR) with specific oligonucleotides. The forward primer added LVPRGS thrombin cleavage site to the N-terminal of the $\mathrm{CBM}_{\mathrm{CBHI}}$ sequence. The forward primer 5' - AAGCTT TACTGGTGCCACGCGGTTCTACACACTACGGCC AG-3' and reverse primer 5' - CGCGGAACCAGCTC GAGTCATTACAGGCACTGAGAGTAGAATG-3' contained cut sites for HindIII and XhoI respectively. The PCR product was purified from a $1 \%$ agarose gel using the Promega Wizard SV gel purification kit (Promega, Fitchburg, USA). Then, it was cloned into the linear pGEM-T vector (Promega) and transformed into Escherichia coli DH5 $\alpha$ chemical competent cells. Transformants carrying the $\mathrm{CBM}_{\mathrm{CBHI}}$ gene were identified by ampicillin resistance and $\beta$-galactosidase blue/white screening. pGEM-T + CBM was isolated using Promega Wizard Plus SV miniprep DNA purification system. The recombinant plasmid and pSMT3 expression vector, which encodes a 6HisSUMO N-terminal tag (Mossessova and Lima 2000), were digested with HindIII and XhoI. The digested fragments were purified from 1\% agarose gel as above, ligated using Promega T4 DNA ligase and transformed into E. coli
DH5 $\alpha$. pSMT3 + CBM was extracted from single colonies that could grow in presence of kanamycin $50 \mu \mathrm{g} / \mathrm{mL}$, sequenced to be sure there were no unwanted mutations and used to transform E. coli Rosetta (DE3) strain. Colonies that could grow in presence of kanamycin $50 \mu \mathrm{g} / \mathrm{mL}$ and chloramphenicol $34 \mu \mathrm{g} / \mathrm{mL}$ were tested for protein production on a small scale. Cells that could overexpress the CBM-SUMO fusion protein were frozen away at $-80^{\circ} \mathrm{C}$ with $20 \%$ glycerol.

\section{$\mathrm{CBM}_{\mathrm{CBHI}}$ expression and purification}

$50 \mathrm{~mL}$ cultures of $E$. coli carrying the CBM-SUMO gene were grown overnight on $2 \mathrm{XYT}$ medium in presence of kanamycin $(50 \mu \mathrm{g} / \mathrm{mL})$ and chloramphenicol $(34 \mu \mathrm{g} / \mathrm{mL})$ at $37^{\circ} \mathrm{C}$ and used to inoculate $1 \mathrm{~L}$ of the same medium. The cultures were grown under constant shaking at $37^{\circ} \mathrm{C}$ until the optical density at $600 \mathrm{~nm}$ reached 0.8 . Expression was induced by addition of $1 \mathrm{mM}$ IPTG and carried out for 4 hours. The cells were harvested by spinning down the cultures at $14,000 \mathrm{~g}$ for 15 minutes. Next they were suspended in $20 \mathrm{~mL}$ of lysis buffer containing $20 \mathrm{mM}$ Tris- $\mathrm{HCl}, 300 \mathrm{mM} \mathrm{NaCl}, 5 \mathrm{mM}$ imidazole, $1 \mathrm{mM}$ dithiothreitol (DTT), $1 \mathrm{mM}$ phenylmethylsulfonylfluoride (PMSF), pH 8.0. Finally, the cell suspension was freezedthawed, sonicated for 6 minutes and centrifuged at $34,000 \mathrm{~g}$ for 30 minutes. The supernatant was loaded on a column with $2 \mathrm{~mL}$ of nickel-nitrilotriacetic acid (Ni-NTA) resin (Qiagen, Crawley, UK) previously equilibrated with 10 volumes of lysis buffer. The column was washed with 4 volumes of wash buffer $(20 \mathrm{mM}$ Tris- $\mathrm{HCl}, 1 \mathrm{M} \mathrm{NaCl}$, $5 \mathrm{mM}$ imidazole, $5 \%(\mathrm{v} / \mathrm{v})$ glycerol, $\mathrm{pH} 8.0)$ and the recombinant protein was eluted with 4 volumes of elution buffer $(20 \mathrm{mM}$ Tris- $\mathrm{HCl}, 100 \mathrm{mM} \mathrm{NaCl}, 300 \mathrm{mM}$ imidazole, 5\% (v/v) glycerol, $1 \mathrm{mM}$ DTT, pH 8.0). The CBMSUMO was further purified using Superdex ${ }^{\text {тм }} 75$ 16/60 (GE Healthcare Biosciences Corporation, Picataway, USA) column previously equilibrated with $20 \mathrm{mM}$ Tris- $\mathrm{HCl}$, $150 \mathrm{mM} \mathrm{NaCl}, \mathrm{pH}$ 8.0. The sample purity was determined by sodium dodecyl sulphate-polyacrylamide gel electrophoresis (SDS-PAGE) and Comassie blue staining.

The $\mathrm{CBM}_{\mathrm{CBHI}}$ was obtained cleaving the fusion protein with $1 \mathrm{U} / \mathrm{mg}$ of thrombin at $18^{\circ} \mathrm{C}$ overnight. It was purified by size-exclusion chromatography as described above.

\section{Activity assays}

The cellulosic substrate Whatman filter paper No. 1 was purchased from Sigma-Aldrich (St. Louis, USA). The TrCBHI, CD $\mathrm{CBHI}_{\text {and }}$ accellerase 1500 (Genencore, Rochester, USA) cellulase preparation were used for hydrolysis. Production and purification of native $\mathrm{TrCBHI}$ and its $\mathrm{CD}_{\mathrm{CBHI}}$ was done following the same protocols used for the homologous protein from $T$. harzianum (Colussi et al. 2010). Hydrolysis was carried out in PCR 
plates and $3 \mathrm{mg}$ filter paper discs were used as substrate. To each well $50 \mu \mathrm{L}$ of CBM-SUMO or $\mathrm{CBM}_{\mathrm{CBHI}}$ in $50 \mathrm{mM}$ citrate buffer ( $\mathrm{pH}$ 5.0) was added. The buffer alone and SUMO in $50 \mathrm{mM}$ citrate buffer ( $\mathrm{pH}$ 5.0) were used as negative controls. The reaction was started by adding $20 \mu \mathrm{L}$ of Accellerase ${ }^{\ominus} 1500, \mathrm{CD}_{\mathrm{CBHI}}$ or $\mathrm{TrCBHI}$ properly diluted in the same buffer. Reactions were performed in quadruplicate at $50^{\circ} \mathrm{C}$. The amount of soluble reducing sugar released by the enzymes was calculated with the dinitrosalicylic acid (DNS) assay (Ghose 1987) using glucose as a standard. Buffer, protein and substrate blanks were measured for every assay and were subtracted from the experimental data.

\section{Results}

\section{$\mathrm{CBM}_{\mathrm{CBHI}}$ expression and purification}

The $\mathrm{CBM}_{\mathrm{CBHI}}$ gene was overexpressed in E. coli fused to a 6 His-SUMO tag. The tag allowed expression, purification and easier concentration of the protein, as the $\mathrm{CBM}_{\mathrm{CBHI}}$ has a molecular weight (MW) of only $3.8 \mathrm{kDa}$ and the CBM-SUMO MW is $19.2 \mathrm{kDa}$. More than $40 \mathrm{mg}$ of the recombinant protein construct was obtained per liter of culture. We also tried to clone and express the $\mathrm{CBM}_{\mathrm{CBHI}}$ alone, but no expression was detected, probably because small proteins are quickly degraded inside the cell (Cheng and Patel 2004). Figure 1 shows results of the CBM-SUMO purification steps. After Ni-NTA affinity chromatography the sample was loaded on a gel-filtration column to purify it from high MW contaminants and also from low MW contaminants that were released with the cell lysis but could not be visualized by SDS-PAGE. The fusion protein was then

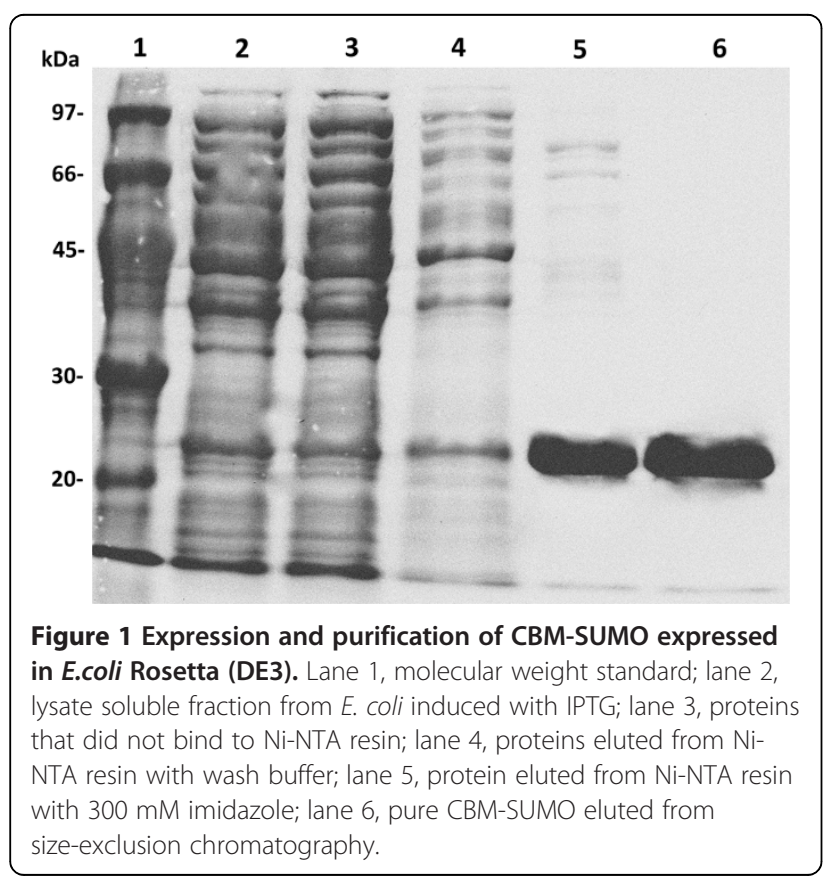

cleaved by thrombin and the released $\mathrm{CBM}_{\mathrm{CBHI}}$ was purified by gel-filtration chromatography. $\mathrm{CBM}_{\mathrm{CBHI}}$ elution was monitored by absorbance at $280 \mathrm{~nm}$, but it could not be visualized by SDS-PAGE due to its low MW.

\section{Hydrolysis reactions}

We first incubated different ratios (w/w) of CBM-SUMO or $\mathrm{CBM}_{\mathrm{CBHI}}$ with TrCBHI or $\mathrm{CD}_{\mathrm{CBHI}}$ for $1 \mathrm{~h}$ and calculated the overall cellulase activity. A clear increase in the rate of filter paper hydrolysis was observed either when TrCBHI was supplemented with $\mathrm{CBM}_{\mathrm{CBHI}}$ or its SUMO-fusion construct (CBM-SUMO). The boost in TrCBHI cellulase activity was approximately constant and close to $25 \%$ (within the experimental errors), no matter what ratios of $\mathrm{CBM}_{\mathrm{CBHI}}$ to $\mathrm{TrCBHI}$ were applied (within 70:1 to 1:2 range of CBM-SUMO:TrCBHI w/w ratios and $\mathrm{CBM}_{\mathrm{CBHI}}$ at the same molar concentration of CBM-SUMO; Figure 2A). On the contrary, CBM-SUMO effect over TrCBHI activity was negative at very high excess of CBM-SUMO over TrCBHI $(-10 \%$ at 70:1 w/w ratio, Figure 2A). At smaller CBM-SUMO doses, its addition had positive synergy with the TrCBHI in filter paper hydrolysis, reaching about $30 \%$ at 1:2 CBMSUMO:TrCBHI (w/w) ratio. The TrCBHI activity improvement promoted by CBM-SUMO and $\mathrm{CBM}_{\mathrm{CBHI}}$ is about the same when the ratio (w/w) of CBM-SUMO: enzyme was 5:1 or less (Figure 2A). Notably, smaller enhancement effect and larger negative contributions at high CBM-SUMO doses were observed when $\mathrm{CD}_{\mathrm{CBHI}}$ was used in the assays (Figure 2B).

To analyze the influence of the $\mathrm{CBM}_{\mathrm{CBHI}}$ addition on the activity of commercial enzymatic preparation, we tested its synergy with the Accellerase ${ }^{\bullet} 1500$. Thus, we incubated different ratios of CBM-SUMO to Accellerase ${ }^{\odot}$ 1500 for $1 \mathrm{~h}$ and calculated the increase in cellulase activity. CBM-SUMO was used in place of $\mathrm{CBM}_{\mathrm{CBHI}}$ because the previous experiment showed that the cellulase activity improvement of the former construct was the same or higher for ratios (w/w) 5:1 or less of CBM:enzyme. As shown in Figure $2 \mathrm{C}$, there was a steady activity improvement reaching values as high as $30 \%$ when a ratio of 1:1 (w/w, CBM-SUMO:enzyme) was used. No reducing sugar could be detected when only CBM-SUMO was incubated with the substrate. We observed an enhancement of about $5 \%$ even when the ratio was as small as 1:100. To test a substrate memory effect we compared direct addition of CBM-SUMO to the enzymatic preparation with the pretreatment of the filter paper with CBM-SUMO prior to the enzymatic hydrolysis reaction. We observed the same improvement in both cases. No improvement in the enzymatic preparation activity was detected upon addition of CBM-SUMO when the soluble carboxymethyl cellulose was used as substrate. 

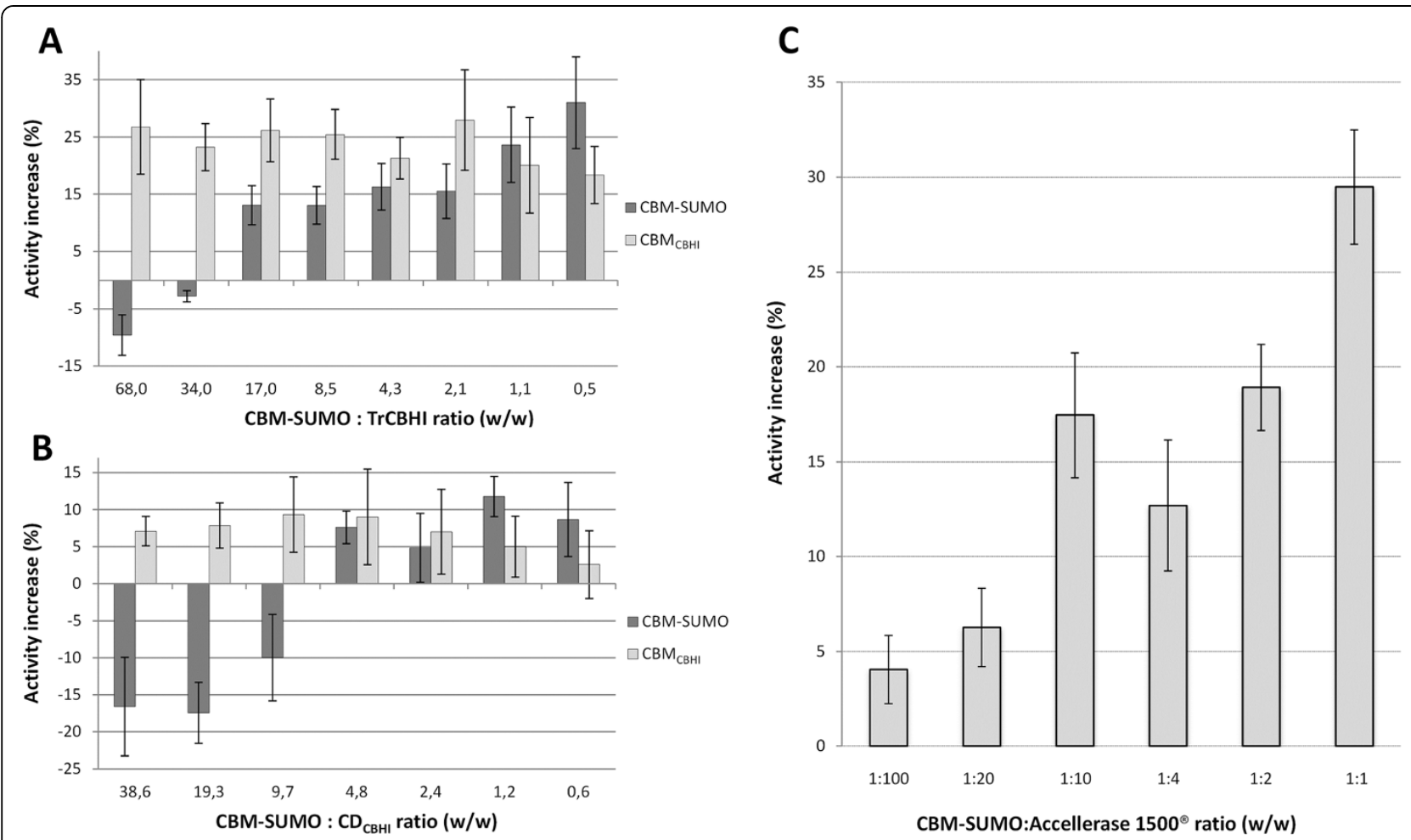

Figure 2 Effect of increasing amounts of CBM-SUMO or $\mathrm{CBM}_{\mathrm{CBH}}$ on filter paper hydrolysis. The ratios of CBM-SUMO to enzyme varied from 70:1 to 1:100 (w/w). Results from CBM $\mathrm{CBH}_{\text {II }}$ and CBM-SUMO are grouped based on the molar concentration of those molecules in the reaction. The results are expressed as percentages of the reaction yields in presence of CBM-SUMO or $\mathrm{CBM}_{\mathrm{CBHI}}$ relative to a negative control experiment carried out without addition of one of these auxiliary proteins. The best enhancement observed was $30 \%$. The cellulase activity after $1 \mathrm{~h}$ reaction was around $1 \mathrm{FPU} / \mathrm{g}$ of substrate and the enzyme concentration used was $\mathbf{A}) 33.3 \mu \mathrm{g} / \mathrm{mL}$ of $\operatorname{TrCBH}, \mathbf{B}) 58,7 \mu \mathrm{g} / \mathrm{mL} \mathrm{of}^{(2 D}$ CBHI and C) $27,5 \mu \mathrm{g} / \mathrm{mL}$ of Accellerase $^{\oplus} 1500$.

The best ratio of CBM-SUMO to enzymatic preparation (1:1, on $\mathrm{w} / \mathrm{w}$ basis) was then used to monitor the hydrolysis of filter paper over time. Surprisingly, the saccharification improvement was about $30 \%$ and this gain was constant over time (Figure 3).

\section{Discussion}

Currently, the main function of CBMs is considered to be to target the CDs to the insoluble substrate, thus increasing the effective cellulase concentration on the polysaccharide surface (Reinikainen et al. 1992; Bolam et al. 1998; Carrard et al. 2000). However, there is a growing body of evidence showing that CBMs from bacterial (Din et al. 1991; Moser et al. 2008) and fungal cellulases (Gao et al. 2001; Xiao et al. 2001; Lemos et al. 2003; Pinto et al. 2004; Wang et al. 2008; Hall et al. 2011) act in the amorphogenesis of cellulose. On the other hand, several studies reported that CBMs have no disruptive activity (Gill et al. 1999; Carrard et al. 2000; Saloheimo et al. 2002) or do not increase the saccharification rates if incubated simultaneously with a cellulase cocktail (Hall et al. 2011). To address this contradictory evidence we set out to study the effect of addition of CBMs on the filter paper hydrolysis by the well-studied TrCBHI, its catalytic domain and a commercial cellulase cocktail.

When the ratios $(\mathrm{w} / \mathrm{w})$ of $\mathrm{CBM}_{\mathrm{CBHI}}$ or CBM-SUMO to $\operatorname{TrCBHI}$ was $5: 1$ or less the observed increase in the activity was the same within the experimental errors. This can be explained by the fact that the SUMO does not interact with cellulose, what was confirmed by the negative controls (results not shown). This might be relevant for application point of view because it is easier and cheaper to produce CBM-SUMO than $\mathrm{CBM}_{\mathrm{CBHI}}$ as the production of the former construct does not involve partial digestion and further purification steps. When the ratio between CBM to TrCBHI was 10:1 or higher the overall cellulase activity decreases for reactions in presence of CBM-SUMO but not for the ones in presence of $\mathrm{CBM}_{\mathrm{CBHI}}$. As the activity did not decrease when $\mathrm{CBM}_{\mathrm{CBHI}}$ was added at the same molar concentration, it probably means that the cellulose binding sites were not saturated. However, the SUMO domain of the CBMSUMO fusion protein is about 4 times bigger than the $\mathrm{CBM}_{\mathrm{CBHI}}$. Therefore, the CBM-SUMO might lead to a steric hindrance at the cellulose accessible surface before the binding sites saturation was observed. As a 


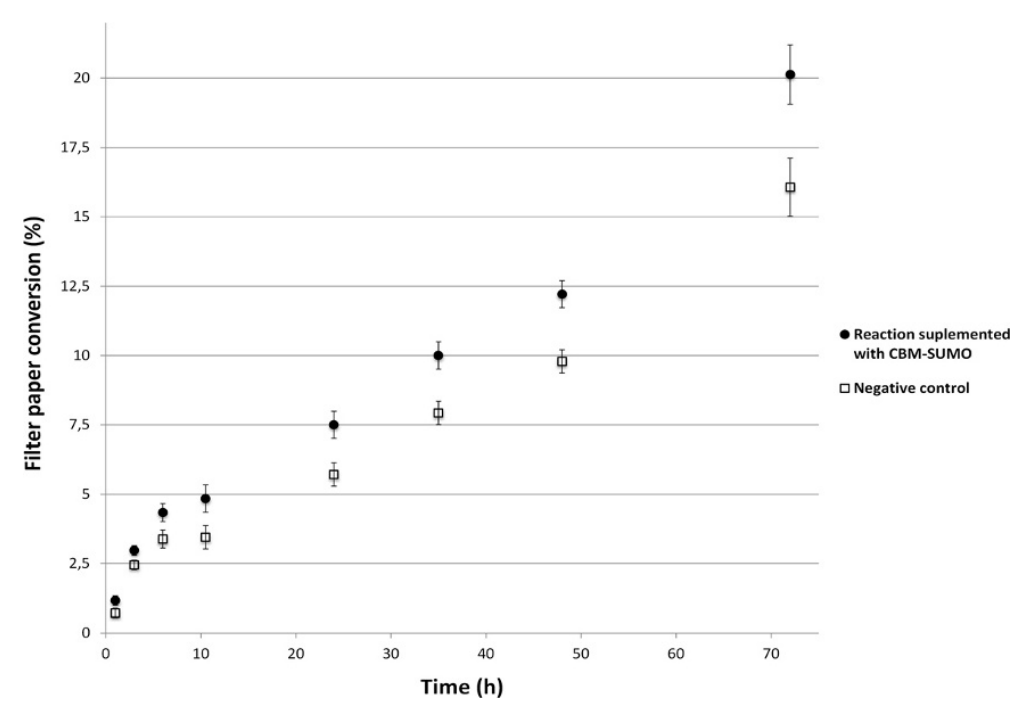

Figure 3 Hydrolysis profile of filter paper in presence and absence of CBM-SUMO. The recombinant protein produced an increase in sugar release of about 30\% during all the monitored reaction time. Both CBM-SUMO and Accellerase ${ }^{\circledast} 1500$ concentrations were 27,5 $\mu \mathrm{g} / \mathrm{mL}$.

consequence, the steric exclusion effect hampered the approximation of $\operatorname{TrCBHI}$ to cellulose, thus decreasing the observed activity. This result agrees with the negatively cooperative adsorption of $\mathrm{CBHI}$ CBM from $T$. reesei fused to a red-fluorescent protein observed by Sugimoto et al. (2012). The effect observed when $\mathrm{CD}_{\mathrm{CBHI}}$ was used in place of TrCBHI was similar. However, the CBM-SUMO hindrance was stronger and activity-boosting effect was weaker for both CBM-SUMO and $\mathrm{CBM}_{\mathrm{CBHI}}$ reaching $12 \%$ or less.

When CBM-SUMO was incubated with a commercial cellulase preparation, our results clearly show that it does enhance cellulase activity, particularly at low cellulase loadings (about $1 \mathrm{FPU} / \mathrm{g}$ of substrate). It is important to mention that although the loading at which considerable enhancement of cellulose hydrolysis was detected is not very high, it is close to or within the range of the loadings currently used for cellulosic biomass deconstruction in cellulosic bioethanol production studies (3 to $15 \mathrm{FPU} / \mathrm{g}$ of substrate range) (Taherzadeh and Karimi 2007). With that in mind, how can we explain that in previous studies no improvement in cellulose hydrolysis was detected when the CBM incubation was simultaneous (Hall et al. 2011)? One possible explanation is that the authors used a higher cellulase loading. Indeed, our experiments clearly show that the CBM-promoted enhancement of cellulosic activities of the commercial enzymatic preparation is dose-dependent. We could not detect significant activity improvements at cellulase loadings of $2 \mathrm{FPU} / \mathrm{g}$ of substrate or higher.

What is the molecular basis for such enhancement of cellulase activity? The observed enhancement might be result of hydrogen bond disruption between cellulose chains, rendering the substrate less recalcitrant for hydrolysis as has already been demonstrated for other CBMs (Gao et al. 2001; Xiao et al. 2001; Pinto et al. 2004; Wang et al. 2008). Our experimental evidence of the boost in enzymatic hydrolysis yields for the crystalline cellulosic substrate which underwent incubation with CBM prior to application of cellulases clearly indicate that the synergistic effect between the CBMs and the cellulases should be mediated by the decrease in recalcitrance of the substrate.

Although many more studies are needed to understand in detail the substrate modifications promoted by CBMs, the fact that they can enhance cellulose hydrolysis yields at low cellulase loadings, is clearly very important for development of cost-effective processes of cellulose saccharification, which is one of the major bottlenecks for cellulosic bioethanol production.

Our study demonstrates that incubation of recombinant $\mathrm{CBM}_{\mathrm{CBHI}}$ (or its fusion construct with SUMO protein) with a cellobiohydrolase, its catalytic domain or a cellulase commercial preparation has a significant impact on cellulose saccharification when the cellulase activity is in the range of $1 \mathrm{FPU} / \mathrm{g}$ of substrate. The boost is up to $30 \%$ in glucose yield during filter paper hydrolysis. Thus, family 1 CBM addition to cellulase preparations might provide an alternative method to reduce the amount of enzymes needed to deconstruct cellulosic biomass, which might have direct impacts on the paper, textile and bioethanol industries.

\section{Competing interest}

The authors declare that they have no competing interest.

\section{Acknowledgments}

The authors are grateful to FAPESP and CNPq for the financial support for this work via grants \# 2009/05349-6, 2008/56255-9 and 2010/52362-5 (FAPESP) and grant \# 490022/2009-0 (CNPq). 
Received: 24 January 2014 Accepted: 16 March 2014 Published online: 25 April 2014

\section{References}

Atalla RH (1987) The structures of cellulose. ACS Symposium Series, Washington Bogo E, Pellegrini VOA, Malago WJ, Silva FH, Polikarpov I (2010) Expression of three novel cellulases from T. harzianum in Pichia pastoris to obtain its 3D structure and innovative enzymatic activity. In: Abstracts of the III Congresso Brasileiro de Biotecnologia, Fortaleza, Ceará, 12-15 October 2010

Bolam DN, Ciruela A, McQueen-Mason S, Simpson P, Williamson MP, Rixon JE, Boraston A, Hazlewood GP, Gilbert HJ (1998) Pseudomonas cellulose-binding domains mediate their effects by increasing enzyme substrate proximity. Bioch J 331:775-781

Cantarel BL, Coutinho PM, Rancurel C, Bernard T, Lombard V, Henrissat B (2009) The Carbohydrate-Active EnZymes database (CAZy): an expert resource for Glycogenomics. Nucleic Acids Res 37:D233-D238. doi:10.1093/nar/gkn663

Carrard G, Koivula A, Soderlund H, Beguin P (2000) Cellulose-binding domains promote hydrolysis of different sites on crystalline cellulose. Proc Natl Acad Sci USA 97(19):10342-10347. doi: 10.1073/pnas.160216697

CAZy (Carbohydrate Active Enzymes database) (2013). http://www.cazy.org/. Accessed on 26 October 2013

Cheng Y, Patel DJ (2004) An efficient system for small protein expression and refolding. Bioch Biophys Res Commun 317(2):401-405. doi:10.1016/j. bbrc.2004.03.068

Colussi F, Textor LC, Serpa V, Maeda RN, Pereira N, Polikarpov I (2010) Purification, crystallization and preliminary crystallographic analysis of the catalytic domain of the extracellular cellulase CBHI from Trichoderma harzianum. Acta Crystallogr Sect F Struct Biol Cryst Commun 66:1041-1044. doi:10.1107/ s1744309110026886

Colussi F, Serpa V, Delabona PS, Manzine LR, Voltatodio ML, Alves R, Mello BL, Pereira N, Farinas CS, Golubev AM, Santos MAM, Polikarpov I (2011) Purification, and biochemical and biophysical characterization of cellobiohydrolase I from Trichoderma harzianum IOC 3844. J Microbiol Biotechnol 21(8):808-817. doi:10.4014/jmb.1010.10037

Din N, Gilkes NR, Tekant B, Miller RC, Warren AJ, Kilburn DG (1991) Non-hydrolytic disruption of cellulose fibers by the binding domain of a bacterial cellulase. Nat Biotechnol 9(11):1096-1099. doi:10.1038/nbt1191-1096

Gao PJ, Chen GJ, Wang TH, Zhang YS, Liu J (2001) Non-hydrolytic disruption of crystalline structure of cellulose by cellulose binding domain and linker sequence of cellobiohydrolase I from Penicillium janthinellum. Acta Biochimi et Biophys Sinica 33(1):13-18

Ghose TK (1987) Measurement of cellulase activities. Pure Appl Chem 59(2):257-268. doi:10.1351/pac198759020257

Gill J, Rixon JE, Bolam DN, McQueen-Mason S, Simpson PJ, Williamson MP, Hazlewood GP, Gilbert HJ (1999) The type II and X cellulose-binding domains of Pseudomonas xylanase A potentiate catalytic activity against complex substrates by a common mechanism. Biochem J 342:473-480. doi:10.1042/ 0264-6021:3420473

Hall M, Bansal P, Lee JH, Realff MJ, Bommarius AS (2011) Biological pretreatment of cellulose: Enhancing enzymatic hydrolysis rate using cellulose-binding domains from cellulases. Bioresour Technol 102(3):2910-2915. doi:10.1016/j. biortech.2010.11.010

Herve C, Rogowski A, Blake AW, Marcus SE, Gilbert HJ, Knox JP (2010) Carbohydrate-binding modules promote the enzymatic deconstruction of intact plant cell walls by targeting and proximity effects. Proc Natl Acad Sci USA 107(34):15293-15298. doi:10.1073/pnas.1005732107

Hon DNS (1994) Cellulose - a random-walk along its historical path. Cellulose 1 (1):1-25. doi:10.1007/bf00818796

Irwin DC, Spezio M, Walker LP, Wilson DB (1993) Activity studies of 8 purified cellulases - specificity, synergism, and binding domain effects. Biotechnol Bioeng 42(8):1002-1013. doi:10.1002/bit.260420811

Knowles J, Lehtovaara P, Teeri T (1987) Cellulase families and their genes. Trends Biotechnol 5(9):255-261. doi:10.1016/0167-7799(87)90102-8

Knox JP (2008) Revealing the structural and functional diversity of plant cell walls. Curr Opin Plant Biol 11(3):308-313. doi:10.1016/j.pbi.2008.03.001

Lemos MA, Teixeira JA, Domingues MRM, Mota M, Gama FM (2003) The enhancement of the cellulolytic activity of cellobiohydrolase I and endoglucanase by the addition of cellulose binding domains derived from Trichoderma reesei. Enzyme and Microb Technol 32(1):35-40. doi:10.1016/ s0141-0229(02)00235-1
Lynd LR, Weimer PJ, van ZyI WH, Pretorius IS (2002) Microbial cellulose utilization: Fundamentals and biotechnology (vol 66, pg 506, 2002). Microbiol Mol Biol Rev 66(4):739. doi:10.1128/mmbr.66.4.739.2002

Mansfield SD, Mooney C, Saddler JN (1999) Substrate and enzyme characteristics that limit cellulose hydrolysis. Biotechnol Progr 15(5):804-816. doi:10.1021/ bp9900864

Michael RG, Joseph S (2012) Molecular cloning: a laboratory manual. Cold Spring Harbor, New York

Moser F, Irwin D, Chen S, Wilson DB (2008) Regulation and characterization of Thermobifida fusca carbohydrate-binding module proteins E7 and E8. Biotechnol Bioeng 100(6):1066-1077. doi:10.1002/bit.21856

Mossessova E, Lima CD (2000) Ulp1-SUMO crystal structure and genetic analysis reveal conserved interactions and a regulatory element essential for cell growth in yeast. Mol Cell 5(5):865-876. doi:10.1016/s1097-2765(00)80326-3

Pinto R, Moreira S, Mota M, Gama M (2004) Studies on the cellulose-binding domains adsorption to cellulose. Langmuir 20(4):1409-1413. doi:10.1021/ la035611u

Reinikainen T, Ruohonen L, Nevanen T, Laaksonen L, Kraulis P, Jones TA, Knowles JKC, Teeri TT (1992) Investigation of the function of mutated cellulose-binding domains of Trichoderma reesei cellobiohydrolase-I. Proteins 14(4):475-482. doi:10.1002/prot.340140408

Saharay M, Guo H, Smith JC (2010) Mechanism of cellulose degradation by a cellobiohydrolase. CelS. PLoS ONE.. doi:10.1371/journal.pone.0012.947

Saloheimo M, Paloheimo M, Hakola S, Pere J, Swanson B, Nyyssonen E, Bhatia A, Ward M, Penttila M (2002) Swollenin, a Trichoderma reesei protein with sequence similarity to the plant expansins, exhibits disruption activity on cellulosic materials. Eur J Biochem 269(17):4202-4211. doi:10.1046/j.14321033.2002.03095.x

Smith MA, Rentmeister A, Snow CD, Wu T, Farrow MF, Mingardon F, Arnold FH (2012) A diverse set of family 48 bacterial glycoside hydrolase cellulases created by structure-guided recombination. FEBS J 279(24):4453-4465. doi:10.1111/febs.12032

Sugimoto N, Igarashi K, Wada M, Samejima M (2012) Adsorption characteristics of fungal family 1 cellulose-binding domain from Trichoderma reesei cellobiohydrolase I on crystalline cellulose: Negative cooperative adsorption via a steric exclusion effect. Langmuir 28(40):14323-14329. doi:10.1021/la302352k

Taherzadeh MJ, Karimi K (2007) Enzyme-based hydrolysis processes for ethanol from lignocellulosic materials: a review. Bioresour 2(4):707-738

Tomme P, Vantilbeurgh H, Pettersson G, Vandamme J, Vandekerckhove J, Knowles J, Teeri T, Claeyssens M (1988) Studies of the cellulolytic system of Trichoderma reesei QM-9414 - analysis of domain function in 2 cellobiohydrolases by limited proteolysis. Eur J Biochem 170(3):575-581. doi:10.1111/j.1432-1033.1988.tb13736.x

Varnai A, Siika-aho M, Viikari L (2013) Carbohydrate-binding modules (CBMs) revisited: reduced amount of water counterbalances the need for CBMs. Biotechnol Biofuels 6:30-42. doi:10.1186/1754-6834-6-30

Wang L, Zhang Y, Gao P (2008) A novel function for the cellulose binding module of cellobiohydrolase I. Sci China Ser C Life Sci 51(7):620-629. doi:10.1007/s11427-008-0088-3

Xiao ZZ, Gao PJ, Qu YB, Wang TH (2001) Cellulose-binding domain of endoglucanase III from Trichoderma reesei disrupting the structure of cellulose. Biotechnol Lett 23(9):711-715. doi:10.1023/a:1010325122851

\section{doi:10.1186/s13568-014-0036-9}

Cite this article as: Mello and Polikarpov: Family 1 carbohydrate

binding-modules enhance saccharification rates. AMB Express 2014 4:36.

\section{Submit your manuscript to a SpringerOpen ${ }^{\odot}$ journal and benefit from:}

- Convenient online submission

- Rigorous peer review

- Immediate publication on acceptance

- Open access: articles freely available online

- High visibility within the field

- Retaining the copyright to your article

Submit your next manuscript at $>$ springeropen.com 